\title{
Review
}

\section{Brain cannabinoid receptor 2: expression, function and modulation}

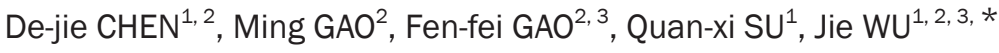

${ }^{1}$ Department of Neurology, Yunfu People's Hospital, Yunfu 527300, China; ${ }^{2}$ Department of Neurobiology, Barrow Neurological Institute, St Joseph's Hospital and Medical Center, Phoenix, AZ 85013-4409, USA; ${ }^{3}$ Department of Pharmacology, Shantou University Medical

College, Shantou 515041, China

\begin{abstract}
Cannabis sativa (marijuana) is a fibrous flowering plant that produces an abundant variety of molecules, some with psychoactive effects. At least $4 \%$ of the world's adult population uses cannabis annually, making it one of the most frequently used illicit drugs in the world. The psychoactive effects of cannabis are mediated primarily through cannabinoid receptor (CBR) subtypes. The prevailing view is that $C_{1} R$ s are mainly expressed in the central neurons, whereas $C_{2} R$ s are predominantly expressed in peripheral immune cells. However, this traditional view has been challenged by emerging strong evidence that shows $\mathrm{CB}_{2} \mathrm{Rs}$ are moderately expressed and function in specific brain areas. New evidence has demonstrated that brain $\mathrm{CB}_{2} \mathrm{Rs}$ modulate animal drug-seeking behaviors, suggesting that these receptors may exist in brain regions that regulate drug addiction. Recently, we further confirmed that functional $\mathrm{CB}_{2} \mathrm{Rs}$ are expressed in mouse ventral tegmental area (VTA) dopamine (DA) neurons and that the activation of VTA CB $\mathrm{R}_{2}$ reduces neuronal excitability and cocaine-seeking behavior. In addition, $\mathrm{CB}_{2} \mathrm{R}$-mediated modulation of hippocampal $\mathrm{CA} 3$ neuronal excitability and network synchronization has been reported. Here, we briefly summarize recent lines of evidence showing how $\mathrm{CB}_{2} \mathrm{Rs}$ modulate function and pathophysiology in the CNS.
\end{abstract}

Keywords: cannabis; brain cannabinoid receptor 2; GPCR; neuronal excitability; psychiatric disorders; neurological disorders; drug addiction

Acta Pharmacologica Sinica (2017) 38: 312-316; doi: 10.1038/aps.2016.149; published online 9 Jan 2017

\section{Introduction}

The cannabinoid type 2 receptor $\left(\mathrm{CB}_{2} \mathrm{R}\right)$ is a G-protein-coupled receptor that was cloned in $1993^{[1]}$. Since then, the expression and function of $\mathrm{CB}_{2} \mathrm{Rs}$ in the brain have been debated. Early studies suggested that $\mathrm{CB}_{2} \mathrm{Rs}$ were absent in the brain because $\mathrm{CB}_{2}$ mRNA transcripts were not detected in brain tissue using various methods ${ }^{[2-5]}$. Based on these findings, $\mathrm{CB}_{2} \mathrm{Rs}$ have been considered the "peripheral" cannabinoid receptor $^{[1,6,7]}$. Recently, this concept has been challenged by the identification of $\mathrm{CB}_{2} \mathrm{Rs}$ throughout the central nervous system (CNS) ${ }^{[5,6]}$. Compared with $\mathrm{CB}_{1}$ Rs, brain $\mathrm{CB}_{2}$ Rs exhibit several unique features: (1) Brain $\mathrm{CB}_{2} \mathrm{Rs}$ have lower expression levels than $C_{1}$ Rs, suggesting that $C_{2}$ Rs may not mediate the effect of cannabis under normal physiological conditions. (2) Brain $\mathrm{CB}_{2}$ Rs are highly inducible; thus, under some pathological conditions (eg, addiction, inflammation, anxiety), $\mathrm{CB}_{2} \mathrm{R}$ expres-

\footnotetext{
*To whom correspondence should be addressed.

E-mail jiewu@email.arizona.edu

Received 2016-07-11 Accepted 2016-10-18
}

sion is quickly enhanced in the brain ${ }^{[8]}$. This finding suggests a close relationship between the alteration of $\mathrm{CB}_{2} \mathrm{R}$ expression/ function and various psychiatric and neurological diseases. (3) Brain $\mathrm{CB}_{2} \mathrm{Rs}$ have a specific distribution. Given that they are chiefly expressed in neuronal somatodendritic areas ${ }^{[9]}$ (postsynaptic), the activation of $\mathrm{CB}_{2}$ Rs may lead to opposing effects from $\mathrm{CB}_{1}$ Rs. For example, $\mathrm{CB}_{1}$ Rs are predominantly expressed on neuronal terminals, especially on GABAergic terminals (presynaptic) in ventral tegmental area (VTA) dopamine (DA) neurons ${ }^{[10]}$. The activation of $\mathrm{CB}_{1}$ Rs reduces GABA release onto DA neurons, leading to an increase in DA neuronal firing through a disinhibition mechanism. However, $\mathrm{CB}_{2} \mathrm{Rs}$ are mainly located on postsynaptic somatodendritic areas, and the activation of $\mathrm{CB}_{2}$ Rs reduces VTA DA neuron firing and excitability ${ }^{[11]}$. Considering these characteristics, $\mathrm{CB}_{2} \mathrm{Rs}$ appear to be an important substrate for neuroprotection ${ }^{[12]}$, and targeting $\mathrm{CB}_{2}$ Rs will likely offer a novel therapeutic strategy for treating neuropsychiatric and neurological diseases without typical $\mathrm{CB}_{1} \mathrm{R}$-mediated side effects ${ }^{[13]}$. Thus, an urgent need to understand the functional effects of $\mathrm{CB}_{2} \mathrm{Rs}$ in the brain has emerged. 
Unfortunately, $\mathrm{CB}_{2} \mathrm{R}$-mediated modulation of neuronal functions, including ion channels, receptors, synaptic transmission and plasticity, and neuronal networks in the CNS, has not been well investigated, and to date, studies of the functional effects of $\mathrm{CB}_{2}$ Rs in neurons have ignited debate and controversy due to the following reasons: (1) a lack of highly selective $\mathrm{CB}_{2} \mathrm{R}$ antibodies ${ }^{[14]}$; (2) a lack of full knockout (KO) $\mathrm{CB}_{2} \mathrm{R}$ mice as the two types of $\mathrm{CB}_{2} \mathrm{R} \mathrm{KO}$ mice that have been recently made available are partial knockouts ${ }^{[7]}$; and (3) under some conditions, $\mathrm{CB}_{1} \mathrm{R}$ and $\mathrm{CB}_{2} \mathrm{R}$ can form a heteromer ${ }^{[15]}$, which makes the identification of $\mathrm{CB}_{2} \mathrm{R}$ function even more complex and difficult. Nevertheless, by combining multiple experimental approaches, several recent papers have described $\mathrm{CB}_{2} \mathrm{R}$ expression and function in the brain neurons. Recently, we reported that functional $\mathrm{CB}_{2} \mathrm{R}$ was expressed in VTA DA neurons, and activation of VTA $\mathrm{CB}_{2}$ Rs reduces neuronal excitability and cocaine-seeking behavior ${ }^{[11]}$. It has been reported that $\mathrm{CB}_{2} \mathrm{R}$ modulates hippocampal CA1 synaptic plasticity ${ }^{[16]}$ and $C A 3$ neural plasticity and synchronization ${ }^{[17]}$. In addition, a recent report showed that $\mathrm{CB}_{2} \mathrm{R}$-dependent inhibition of DA release underlies the positive allosteric modulation of the M4 muscarinic receptor in antipsychotic-like effects ${ }^{[18]}$. These accumulating lines of evidence suggest that brain $\mathrm{CB}_{2} \mathrm{Rs}$ are important in the modulation of brain function and disorders.

\section{Brain $\mathrm{CB}_{\mathbf{2}} \mathbf{R}$ expression}

Although early studies were not able to detect $\mathrm{CB}_{2}$ mRNA transcripts in brain tissue using various methods ${ }^{[2-5]}$, recent lines of evidence show that significant $\mathrm{CB}_{2}$ mRNA has been detected by in situ hybridization (ISH) in the globus pallidus of non-human primates ${ }^{[19]}$. RT-PCR analysis has also been used to detect $\mathrm{CB}_{2}$ mRNA expression in various brain regions, including the retina ${ }^{[20]}$, cortex ${ }^{[19,21-23]}$, striatum ${ }^{[2,23]}$, hippocam$\operatorname{pus}^{[17,19,24]}$, amygdala ${ }^{[22,23]}$, brainstem ${ }^{[25]}$, and cerebellum ${ }^{[26]}$. Furthermore, two $\mathrm{CB}_{2}$ mRNA transcripts $\left(\mathrm{CB}_{2 \mathrm{~A}}\right.$ and $\left.\mathrm{CB}_{2 \mathrm{~B}}\right)$ are transcribed from two independent promoters in rodent and human tissue ${ }^{[21]}$. Recently, we have confirmed that $\mathrm{CB}_{2}$ mRNA is relatively highly expressed in VTA DA neurons ${ }^{[11]}$. Moreover, immunoblot and immunohistochemical (IHC) assays have detected significant $\mathrm{CB}_{2}$-like bands or immunostaining in various brain regions ${ }^{[25,27-30]}$, including the VTA ${ }^{[11]}$. These findings suggest that $\mathrm{CB}_{2} \mathrm{R}$ expression exists not only in peripheral tissue but also in the brain, although the $C_{2} R$ expression level in the brain is much lower than that of $C_{1} R$. This low-level brain $\mathrm{CB}_{2} \mathrm{R}$ expression suggests that $\mathrm{CB}_{2} \mathrm{R}$ may not participate in important brain physiology function; thus, unlike $\mathrm{CB}_{1} \mathrm{Rs}$ that mediate serious psychiatric side effects after activation, pharmacological intervention of $\mathrm{CB}_{2}$ Rs has much fewer side effects. In addition to brain neurons, brain glia cells express $\mathrm{CB}_{2} \mathrm{Rs}^{[31,32]}$, where $\mathrm{CB}_{2}$ Rs play an important role in the modulation of central immune function ${ }^{[33]}$ and neuroinflammationassociated diseases ${ }^{[34-36]}$.

\section{Brain $\mathrm{CB}_{\mathbf{2}} \mathbf{R}$ distribution and function}

Although both $\mathrm{CB}_{1}$ Rs and $\mathrm{CB}_{2}$ Rs are $\mathrm{G}$-protein $\left(\mathrm{G}_{\mathrm{i} / \mathrm{o}}\right)$-coupled receptors, they exhibit different distributions. In general, the
$\mathrm{CB}_{1}$ Rs are mainly expressed in GABAergic neuronal axon terminals, including in VTA GABA neurons ${ }^{[37,38]}$ and hippocampal CCK-positive GABA neurons ${ }^{[39]}$. The activation of $\mathrm{CB}_{1} \mathrm{Rs}$ reduces presynaptic GABA release, eliminates GABAergic inhibitory control of postsynaptic neurons, and excites these postsynaptic neurons through this dis-inhibition role. However, the $\mathrm{CB}_{2} \mathrm{Rs}$ are mainly expressed in the postsynaptic cell body ${ }^{[11,17]}$; thus, the activation of these postsynaptic $\mathrm{CB}_{2} \mathrm{Rs}$ usually hyperpolarizes the membrane potential and inhibits postsynaptic neuronal function. Therefore, this difference in distribution results in opposite effects after $C_{1} R$ and $C_{2} R$ activation. Activation of $\mathrm{CB}_{2} \mathrm{Rs}$ reduces neuronal excitability through different mechanisms. In VTA DA neurons, activation of $\mathrm{CB}_{2} \mathrm{Rs}$ decreases neuronal excitability through the $\mathrm{CB}_{2} \mathrm{R}$-associated modulation of $\mathrm{K}^{+}$channel function ${ }^{[11]}$. In prefrontal cortical neurons, intracellular $\mathrm{CB}_{2} \mathrm{Rs}$ are coupled to the $\mathrm{G}_{\mathrm{q} 11}-\mathrm{PLC}-\mathrm{IP}_{3}$ pathway, which opens the $\mathrm{Ca}^{2+}$-dependent $\mathrm{Cl}^{-}$channels, hyperpolarizes the cell membrane and results in neuronal inhibition ${ }^{[40]}$. In hippocampal CA3/CA2 pyramidal neurons, activation of $\mathrm{CB}_{2} \mathrm{Rs}$ triggers activation of the $\mathrm{Na}^{+}$/ Bicarbonate co-transporter and causes a long-term neuronal hyperpolarization. This $\mathrm{CB}_{2} \mathrm{R}$ activation occurs in a purely self-regulatory manner, robustly alters the input/output function of CA3 pyramidal cells, and modulates gamma oscillations in vivo ${ }^{[17]}$. The relatively high expression of $\mathrm{CB}_{2} \mathrm{Rs}$ in midbrain DA neurons suggests that they modulate a variety of important DA-associated behaviors ${ }^{[41]}$. It has been reported that $\mathrm{CB}_{2}$ Rs modulate food intake, body weight ${ }^{[42-45]}$, depres$\operatorname{sion}^{[46]}$, anxiety ${ }^{[22,47]}$, and schizophrenia-like behavior ${ }^{[23,48]}$. Recent reports emerging from several labs, including ours, have shown that brain $\mathrm{CB}_{2}$ Rs play a pivotal role in reducing cocaine, alcohol, and nicotine addiction ${ }^{[49-51]}$. Collectively, these lines of evidence strongly suggest an important impact of $\mathrm{CB}_{2} \mathrm{Rs}$ in the mesocorticolimbic system, as well as critical roles of $\mathrm{CB}_{2} \mathrm{Rs}$ in various brain functions, including psychiatric, cognitive, and neurobiological activity.

\section{Inducible feature of brain $\mathrm{CB}_{2} \mathrm{Rs}$ and their modulation in neurological and psychiatric disorders}

The most attractive property of the $C_{2} R$ is its inducible feature. Brain $\mathrm{CB}_{2} \mathrm{Rs}$ are expressed at low levels under physiological conditions; however, in pathological conditions, such as neuropathic pain ${ }^{[52]}$, stroke ${ }^{[53]}$, traumatic brain injury ${ }^{[54]}$, neurodegenerative diseases ${ }^{[55-57]}$ or drug addiction ${ }^{[58,59]}, \mathrm{CB}_{2} \mathrm{R}$ expression up-regulates quickly and profoundly. This inducible feature lets $\mathrm{CB}_{2} \mathrm{Rs}$ serve as a disease-associated target, and pharmacotherapeutic manipulation of $\mathrm{CB}_{2} \mathrm{Rs}$ can treat diseases without side effects. For example, the mesocorticolimbic DA system is a key brain circuit implicated in a number of drug addictions. Alterations of the mesocorticolimbic DA circuit are the major cellular mechanisms to promote or prevent drug reward, dependence, and addiction. Emerging evidence has demonstrated that $\mathrm{CB}_{2} \mathrm{Rs}$ modulate animal drug-seeking behaviors, including cocaine, alcohol, and nicotine ${ }^{[49-51]}$, suggesting a significant impact of brain $\mathrm{CB}_{2} \mathrm{Rs}$ in animal drug reward, dependence, and addiction. Given the 
lack of psychoactivity demonstrated by selective $\mathrm{CB}_{2} \mathrm{R}$ agonists, $\mathrm{CB}_{2} \mathrm{R}$ ligands have been developed as new candidates for the treatment of a variety of neurological and psychiatric disorders $^{[13,60,61]}$, including pain ${ }^{[62-65]}$, neuroinflammation ${ }^{[66]}$, stroke $^{[67,68]}$, Alzheimer's disease ${ }^{[69]}$, Parkinson's disease, and Huntington's disease $\mathrm{e}^{[36,70-75]}$. Three medicines that activate cannabinoid $\mathrm{CB}_{1} / \mathrm{CB}_{2}$ receptors are now used in clinics: Cesamet (nabilone), Marinol (dronabinol; $\Delta^{9}$-tetrahydrocannabinol $\left[\Delta^{9}\right.$ $\mathrm{THC}]$ ), and Sativex ( $\Delta^{9}$-THC with cannabidiol). Additionally, a selective $\mathrm{CB}_{2} \mathrm{R}$ agonist "Resunab ${ }^{\mathrm{TM}}$ " has been designated by the FDA for a fast-track development program in a Phase II human clinical trial for scleroderma. However, significant attention is currently being directed at the possibility of developing medicines from compounds that can activate $\mathrm{CB}_{2} \mathrm{Rs}$ at doses that induce little or no $\mathrm{CB}_{1} \mathrm{R}$ activation. Accumulating lines of evidence have demonstrated that many of the adverse effects induced by mixed $C_{1} / \mathrm{CB}_{2}$ receptor agonists result from $C_{1} R$ rather than from $C_{2} R$ activation and that $C_{2} R$ selective agonists have a number of important potential therapeutic applications ${ }^{[60]}$. Therefore, we anticipate the emergence of new drugs that modulate $\mathrm{CB}_{2} \mathrm{Rs}$ once a better understanding of the cannabinoid receptors is gained.

\section{Limitation of brain $\mathrm{CB}_{2} \mathrm{Rs}$ as a therapeutic target}

The major challenge of how to selectively target brain $\mathrm{CB}_{2} \mathrm{Rs}$ without affecting peripheral $C_{2}$ Rs remains, as $C_{2} R$ levels are much higher in peripheral tissues (eg, $\mathrm{T}$-cells in the spleen) than in the brain. Thus, systemic exposure of $\mathrm{CB}_{2} \mathrm{R}$ ligands to activate brain $C_{2}$ Rs will always activate peripheral $C_{2} R s$. We have two thoughts regarding this challenge: 1) Brain $\mathrm{CB}_{2} \mathrm{Rs}$ are dramatically inducible, meaning they are up-regulated during disease conditions such as addiction, degeneration and inflammation. This pathology-associated increase significantly enhances the benefit to side-effect ratio ${ }^{[76]}$. 2) Activation of brain $\mathrm{CB}_{2} \mathrm{Rs}$ protects neurons from pathological conditions (eg, addiction, anxiety, stroke, epilepsy, pain) while also activating peripheral $\mathrm{CB}_{2} \mathrm{Rs}$ (eg, T-cells), which may cause side effects in addition to central therapeutic effects. However, peripheral $\mathrm{CB}_{2} \mathrm{R}$ activation will reduce the immune response and prevent an over-inflammatory reaction, which are beneficial for central protective effects. Therefore, the activation of peripheral $\mathrm{CB}_{2} \mathrm{Rs}$ may not always induce side effects when brain $\mathrm{CB}_{2} \mathrm{Rs}$ are activated, but rather, both central and peripheral $\mathrm{CB}_{2} \mathrm{Rs}$ may work together to protect brain neurons from pathological alterations through both neuronal and immune mechanisms. Figure 1 shows a diagram of the impact of brain $\mathrm{CB}_{2} \mathrm{R}$ distribution, function and disease.

\section{Acknowledgements}

This work was supported by the Barrow Neuroscience Foundation (Ming GAO) and University of Arizona College of Medicine, Phoenix-Barrow Neurological Institute Collaboration Grant (Jie WU and Ming GAO).

\section{References}

1 Munro S, Thomas KL, Abu-Shaar M. Molecular characterization of a

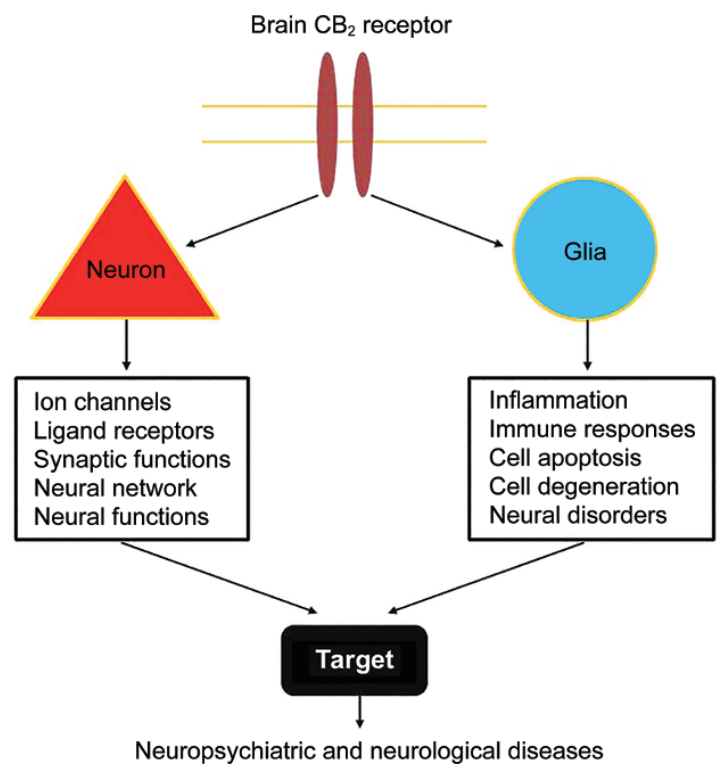

Figure 1. A diagram summarizing brain $\mathrm{CB}_{2} \mathrm{R}$ expression and function and the association with neuropsychiatric and neurological diseases. $\mathrm{CB}_{2} \mathrm{Rs}$ are expressed in brain neurons, where they participate in the modulation of a variety of neural functions and disorders. $\mathrm{CB}_{2} \mathrm{Rs}$ are also expressed in brain glia cells, where they modulate immune function and neuroinflammatory responses. Therefore, brain $\mathrm{CB}_{2} \mathrm{Rs}$ are an important target for the modulation of brain function and disease.

peripheral receptor for cannabinoids. Nature 1993; 365: 61-5.

2 Galiègue S, Mary S, Marchand J, Dussossoy D, Carrière D, Carayon P, et al. Expression of central and peripheral cannabinoid receptors in human immune tissues and leukocyte subpopulations. Eur J Biochem 1995; 232: 54-61.

3 Schatz AR, Lee M, Condie RB, Pulaski JT, Kaminski NE. Cannabinoid receptors $\mathrm{CB}_{1}$ and $\mathrm{CB}_{2}$ : a characterization of expression and adenylate cyclase modulation within the immune system. Toxicol Appl Pharmacol 1997; 142: 278-87.

4 McCoy KL, Matveyeva M, Carlisle SJ, Cabral GA. Cannabinoid inhibition of the processing of intact lysozyme by macrophages: evidence for $\mathrm{CB}_{2}$ receptor participation. J Pharmacol Exp Ther 1999; 289: 1620-5.

5 Burdyga G, Lal S, Varro A, Dimaline R, Thompson DG, Dockray GJ. Expression of cannabinoid $\mathrm{CB}_{1}$ receptors by vagal afferent neurons is inhibited by cholecystokinin. J Neurosci 2004; 24: 2708-15.

6 Buckley NE, McCoy KL, Mezey E, Bonner T, Zimmer A, Felder CC, et al. Immunomodulation by cannabinoids is absent in mice deficient for the cannabinoid $\mathrm{CB}_{2}$ receptor. Eur J Pharmacol 2000; 396: 141-9.

7 Buckley NE. The peripheral cannabinoid receptor knockout mice: an update. Br J Pharmacol 2008; 153: 309-18.

8 Miller LK, Devi LA. The highs and lows of cannabinoid receptor expression in disease: mechanisms and their therapeutic implications. Pharmacol Rev 2011; 63: 461-70.

9 Onaivi ES, Ishiguro H, Gong JP, Patel S, Meozzi PA, Myers L, et al. Functional expression of brain neuronal $\mathrm{CB}_{2}$ cannabinoid receptors are involved in the effects of drugs of abuse and in depression. Ann N Y Acad Sci 2008; 1139: 434-49.

10 Onaivi ES, Ishiguro $\mathrm{H}, \mathrm{Gu} \mathrm{S}$, Liu QR. CNS effects of $\mathrm{CB}_{2}$ cannabinoid receptors: beyond neuro-immuno-cannabinoid activity. J Psychopharmacol (Oxford) 2012; 26: 92-103. 
11 Zhang HY, Gao M, Liu QR, Bi GH, Li X, Yang HJ, et al. Cannabinoid $\mathrm{CB}_{2}$ receptors modulate midbrain dopamine neuronal activity and dopamine-related behavior in mice. Proc Natl Acad Sci U S A 2014; 111: E5007-15.

12 Pacher P, Mechoulam R. Is lipid signaling through cannabinoid 2 receptors part of a protective system? Prog Lipid Res 2011; 50: 193-211.

13 Fernández-Ruiz J, Pazos MR, García-Arencibia M, Sagredo 0, Ramos $\mathrm{JA}$. Role of $\mathrm{CB}_{2}$ receptors in neuroprotective effects of cannabinoids. Mol Cell Endocrinol 2008; 286: S91-6.

14 Cécyre B, Thomas S, Ptito M, Casanova C, Bouchard JF. Evaluation of the specificity of antibodies raised against cannabinoid receptor type 2 in the mouse retina. Naunyn Schmiedebergs Arch Pharmacol 2014; 387: 175-84.

15 Callén L, Moreno E, Barroso-Chinea P, Moreno-Delgado D, Cortés A, Mallol J, et al. Cannabinoid receptors $\mathrm{CB}_{1}$ and $\mathrm{CB}_{2}$ form functional heteromers in brain. J Biol Chem 2012; 287: 20851-65.

$16 \mathrm{Kim} \mathrm{J,} \mathrm{Li}$ Y. Chronic activation of $\mathrm{CB}_{2}$ cannabinoid receptors in the hippocampus increases excitatory synaptic transmission. J Physiol (Lond) 2015; 593: 871-86.

17 Stempel AV, Stumpf A, Zhang HY, Özdoğan T, Pannasch U, Theis AK, et al. Cannabinoid type 2 receptors mediate a cell type-specific plasticity in the hippocampus. Neuron 2016; 90: 795-809.

18 Foster DJ, Wilson JM, Remke DH, Mahmood MS, Uddin MJ, Wess J, et al. Antipsychotic-like effects of M4 positive allosteric modulators are mediated by $\mathrm{CB}_{2}$ receptor-dependent inhibition of dopamine release. Neuron 2016; 91: 1244-52.

19 Lanciego JL, Barroso-Chinea P, Rico AJ, Conte-Perales L, Callén L, Roda $\mathrm{E}$, et al. Expression of the mRNA coding the cannabinoid receptor 2 in the pallidal complex of Macaca fascicularis. J Psychopharmacol (Oxford) 2011; 25: 97-104.

20 Lu Q, Straiker A, Lu Q, Maguire G. Expression of $\mathrm{CB}_{2}$ cannabinoid receptor mRNA in adult rat retina. Vis Neurosci 2000; 17: 91-5.

21 Liu QR, Pan CH, Hishimoto A, Li CY, Xi ZX, Llorente-Berzal A, et al. Species differences in cannabinoid receptor 2 (CNR2 gene): identification of novel human and rodent $\mathrm{CB}_{2}$ isoforms, differential tissue expression and regulation by cannabinoid receptor ligands. Genes Brain Behav 2009; 8: 519-30.

22 García-Gutiérrez MS, García-Bueno B, Zoppi S, Leza JC, Manzanares J. Chronic blockade of cannabinoid $\mathrm{CB}_{2}$ receptors induces anxiolytic-like actions associated with alterations in $\mathrm{GABA}_{A}$ receptors. Br J Pharmacol 2012; 165: 951-64.

23 Navarrete F, Pérez-Ortiz JM, Manzanares J. Cannabinoid $\mathrm{CB}_{2}$ receptormediated regulation of impulsive-like behaviour in DBA/2 mice. $\mathrm{Br} J$ Pharmacol 2012; 165: 260-73.

$24 \mathrm{Li} \mathrm{Y,} \mathrm{Kim} \mathrm{J.} \mathrm{Neuronal} \mathrm{expression} \mathrm{of} \mathrm{CB}_{2}$ cannabinoid receptor mRNAs in the mouse hippocampus. Neuroscience 2015; 311: 253-67.

25 Van Sickle MD, Duncan M, Kingsley PJ, Mouihate A, Urbani P, Mackie $\mathrm{K}$, et al. Identification and functional characterization of brainstem cannabinoid $\mathrm{CB}_{2}$ receptors. Science 2005; 310: 329-32.

26 Viscomi MT, Oddi S, Latini L, Pasquariello N, Florenzano F, Bernardi G, et al. Selective $\mathrm{CB}_{2}$ receptor agonism protects central neurons from remote axotomy-induced apoptosis through the PI3K/Akt pathway. J Neurosci 2009; 29: 4564-70.

27 Ashton JC, Friberg D, Darlington CL, Smith PF. Expression of the cannabinoid $\mathrm{CB}_{2}$ receptor in the rat cerebellum: an immunohistochemical study. Neurosci Lett 2006; 396: 113-6.

28 Baek JH, Zheng Y, Darlington CL, Smith PF. Cannabinoid $\mathrm{CB}_{2}$ receptor expression in the rat brainstem cochlear and vestibular nuclei. Acta Otolaryngol 2008; 128: 961-7.

29 Brusco A, Tagliaferro P, Saez T, Onaivi ES. Postsynaptic localization of
$\mathrm{CB}_{2}$ cannabinoid receptors in the rat hippocampus. Synapse 2008; 62: 944-9.

30 Gong JP, Onaivi ES, Ishiguro H, Liu QR, Tagliaferro PA, Brusco A, et al. Cannabinoid $\mathrm{CB}_{2}$ receptors: Immunohistochemical localization in rat brain. Brain Research 2006; 1071: 10-23.

31 Stella N. Cannabinoid and cannabinoid-like receptors in microglia, astrocytes, and astrocytomas. Glia 2010; 58: 1017-30.

32 Cabral GA, Marciano-Cabral F. Cannabinoid receptors in microglia of the central nervous system: immune functional relevance. J Leukoc Biol 2005; 78: 1192-7.

33 Cabral GA, Raborn ES, Griffin L, Dennis J, Marciano-Cabral F. $\mathrm{CB}_{2}$ receptors in the brain: role in central immune function. Br J Pharmacol 2008; 153: 240-51.

34 Pazos MR, Núñez E, Benito C, Tolón RM, Romero J. Role of the endocannabinoid system in Alzheimer's disease: new perspectives. Life Sci 2004; 75: 1907-15.

35 Rivers JR, Ashton JC. The development of cannabinoid CBII receptor agonists for the treatment of central neuropathies. Cent Nerv Syst Agents Med Chem 2010; 10: 47-64.

36 Little JP, Villanueva EB, Klegeris A. Therapeutic potential of cannabinoids in the treatment of neuroinflammation associated with Parkinsons disease. Mini Rev Med Chem 2011; 11: 582-90.

37 Szabo B, Siemes S, Wallmichrath I. Inhibition of GABAergic neurotransmission in the ventral tegmental area by cannabinoids. Eur J Neurosci 2002; 15: 2057-61.

38 Dubreucq S, Durand A, Matias I, Bénard G, Richard E, Soria-Gomez $\mathrm{E}$, et al. Ventral tegmental area cannabinoid type-1 receptors control voluntary exercise performance. Biol Psychiatry 2013; 73: 895-903.

39 Albayram Ö, Passlick S, Bilkei-Gorzo A, Zimmer A, Steinhäuser C. Physiological impact of $\mathrm{CB}_{1}$ receptor expression by hippocampal GABAergic interneurons. Pflugers Arch 2016; 468: 727-37.

40 den Boon FS, Chameau P, Schaafsma-Zhao Q, van Aken W, Bari M, Oddi $\mathrm{S}$, et al. Excitability of prefrontal cortical pyramidal neurons is modulated by activation of intracellular type-2 cannabinoid receptors. Proc Natl Acad Sci U S A 2012; 109: 3534-9.

41 Vlachou S, Panagis G. Regulation of brain reward by the endocannabinoid system: a critical review of behavioral studies in animals. Curr Pharm Des 2014; 20: 2072-88.

42 Agudo J, Martin M, Roca C, Molas M, Bura AS, Zimmer A, et al. Deficiency of $\mathrm{CB}_{2}$ cannabinoid receptor in mice improves insulin sensitivity but increases food intake and obesity with age. Diabetologia 2010; 53: 2629-40.

43 Ignatowska-Jankowska B, Jankowski MM, Swiergiel AH. Cannabidiol decreases body weight gain in rats: involvement of $\mathrm{CB}_{2}$ receptors. Neurosci Lett 2011; 490: 82-4.

44 Emadi L, Jonaidi $\mathrm{H}$, Hosseini Amir Abad E. The role of central $\mathrm{CB}_{2}$ cannabinoid receptors on food intake in neonatal chicks. J Comp Physiol A Neuroethol Sens Neural Behav Physiol 2011; 197: 1143-7.

45 Flake NM, Zweifel LS. Behavioral effects of pulp exposure in mice lacking cannabinoid receptor 2. J Endod 2012; 38: 86-90.

46 García-Gutiérrez MS, Pérez-Ortiz JM, Gutiérrez-Adán A, Manzanares J. Depression-resistant endophenotype in mice overexpressing cannabinoid $\mathrm{CB}_{2}$ receptors. Br J Pharmacol 2010; 160: 1773-84.

47 García-Gutiérrez MS, Manzanares J. Overexpression of $\mathrm{CB}_{2}$ cannabinoid receptors decreased vulnerability to anxiety and impaired anxiolytic action of alprazolam in mice. J Psychopharmacol (Oxford) 2011; 25: 111-20.

48 Ortega-Alvaro A, Aracil-Fernández A, García-Gutiérrez MS, Navarrete $\mathrm{F}$, Manzanares J. Deletion of $\mathrm{CB}_{2}$ cannabinoid receptor induces schizophrenia-related behaviors in mice. Neuropsychopharmacology 2011; 36: 1489-504. 
49 Xi ZX, Peng XQ, Li X, Song R, Zhang HY, Liu QR, et al. Brain cannabinoid $\mathrm{CB}_{2}$ receptors modulate cocaine's actions in mice. Nat Neurosci 2011 14: 1160-6.

50 Navarrete F, Rodríguez-Arias M, Martín-García E, Navarro D, GarcíaGutiérrez MS, Aguilar MA, et al. Role of $\mathrm{CB}_{2}$ cannabinoid receptors in the rewarding, reinforcing, and physical effects of nicotine. Neuropsychopharmacology 2013; 38: 2515-24.

51 Ortega-Álvaro A, Ternianov A, Aracil-Fernández A, Navarrete F, GarcíaGutiérrez MS, Manzanares J. Role of cannabinoid $\mathrm{CB}_{2}$ receptor in the reinforcing actions of ethanol. Addict Biol 2015; 20: 43-55.

52 Svízenská IH, Brázda V, Klusáková I, Dubový P. Bilateral changes of cannabinoid receptor type 2 protein and mRNA in the dorsal root ganglia of a rat neuropathic pain model. J Histochem Cytochem 2013; 61: 529-47.

53 Yu SJ, Reiner D, Shen H, Wu KJ, Liu QR, Wang Y. Time-dependent protection of $\mathrm{CB}_{2}$ receptor agonist in stroke. PLoS One 2015; 10 : e0132487.

54 Lopez-Rodriguez AB, Acaz-Fonseca E, Viveros MP, Garcia-Segura LM. Changes in cannabinoid receptors, aquaporin 4 and vimentin expression after traumatic brain injury in adolescent male mice. Association with edema and neurological deficit. PLoS One 2015; 10: e0128782.

55 Concannon RM, Okine BN, Finn DP, Dowd E. Upregulation of the cannabinoid $\mathrm{CB}_{2}$ receptor in environmental and viral inflammationdriven rat models of Parkinson's disease. Exp Neurol 2016; 283: 204-12.

56 Aso E, Ferrer I. $\mathrm{CB}_{2}$ cannabinoid receptor as potential target against Alzheimer's disease. Front Neurosci 2016; 10: 243.

57 Concannon RM, Okine BN, Finn DP, Dowd E. Differential upregulation of the cannabinoid $\mathrm{CB}_{2}$ receptor in neurotoxic and inflammation-driven rat models of Parkinson's disease. Exp Neurol 2015; 269: 133-41.

58 Agudelo M, Yndart A, Morrison M, Figueroa G, Muñoz K, Samikkannu $\mathrm{T}$, et al. Differential expression and functional role of cannabinoid genes in alcohol users. Drug Alcohol Depend 2013; 133: 789-93.

59 Rivera P, Miguéns M, Coria SM, Rubio L, Higuera-Matas A, BermúdezSilva FJ, et al. Cocaine self-administration differentially modulates the expression of endogenous cannabinoid system-related proteins in the hippocampus of Lewis vs Fischer 344 rats. Int J Neuropsychopharmacol 2013; 16: 1277-93.

60 Pertwee RG. Targeting the endocannabinoid system with cannabinoid receptor agonists: pharmacological strategies and therapeutic possibilities. Philos Trans R Soc Lond B Biol Sci 2012; 367: 335363.

61 Han S, Thatte J, Buzard DJ, Jones RM. Therapeutic utility of cannabinoid receptor type $2\left(\mathrm{CB}_{2}\right)$ selective agonists. J Med Chem 2013; 56: 8224-56.

62 Pertwee RG. Cannabinoid receptors and pain. Prog Neurobiol 2001;
63: 569-611.

63 Malan TP Jr, Ibrahim MM, Lai J, Vanderah TW, Makriyannis A, Porreca F. $\mathrm{CB}_{2}$ cannabinoid receptor agonists: pain relief without psychoactive effects? Curr Opin Pharmacol 2003; 3: 62-7.

64 Jhaveri MD, Sagar DR, Elmes SJ, Kendall DA, Chapman V. Cannabinoid $\mathrm{CB}_{2}$ receptor-mediated anti-nociception in models of acute and chronic pain. Mol Neurobiol 2007; 36: 26-35.

65 Beltramo M. Cannabinoid type 2 receptor as a target for chronic-pain. Mini Rev Med Chem 2009; 9: 11-25.

66 Rom S, Persidsky Y. Cannabinoid receptor 2: potential role in immunomodulation and neuroinflammation. J Neuroimmune Pharmacol 2013; 8: 608-20.

67 Choi IY, Ju C, Anthony Jalin AM, Lee DI, Prather PL, Kim WK. Activation of cannabinoid $\mathrm{CB}_{2}$ receptor-mediated AMPK/CREB pathway reduces cerebral ischemic injury. Am J Pathol 2013; 182: 928-39.

68 Capettini LS, Savergnini SQ, da Silva RF, Stergiopulos N, Santos RA, Mach $\mathrm{F}$, et al. Update on the role of cannabinoid receptors after ischemic stroke. Mediators Inflamm 2012; 2012: 824093.

69 Aso E, Ferrer I. Cannabinoids for treatment of Alzheimer's disease: moving toward the clinic. Front Pharmacol 2014; 5: 37.

70 Fernández-Ruiz J, Moreno-Martet M, Rodríguez-Cueto C, Palomo-Garo C, Gómez-Cañas M, Valdeolivas S, et al. Prospects for cannabinoid therapies in basal ganglia disorders. Br J Pharmacol 2011; 163 : 1365-78.

71 Price DA, Martinez AA, Seillier A, Koek W, Acosta Y, Fernandez $\mathrm{E}$, et al. WIN55,212-2, a cannabinoid receptor agonist, protects against nigrostriatal cell loss in the 1-methyl-4-phenyl-1,2,3,6-tetrahydropyridine mouse model of Parkinson's disease. Eur J Neurosci 2009; 29: 2177-86.

72 García C, Palomo-Garo C, García-Arencibia M, Ramos J, Pertwee R, Fernández-Ruiz J. Symptom-relieving and neuroprotective effects of the phytocannabinoid $\triangle 9$-THCV in animal models of Parkinson's disease. Br J Pharmacol 2011; 163: 1495-506.

73 Gómez-Gálvez Y, Palomo-Garo C, Fernández-Ruiz J, García C. Potential of the cannabinoid $\mathrm{CB}_{2}$ receptor as a pharmacological target against inflammation in Parkinson's disease. Prog Neuropsychopharmacol Biol Psychiatry 2016; 64: 200-8.

74 Palazuelos J, Aguado T, Pazos MR, Julien B, Carrasco C, Resel E, et al. Microglial $\mathrm{CB}_{2}$ cannabinoid receptors are neuroprotective in Huntington's disease excitotoxicity. Brain 2009; 132: 3152-64.

75 Sagredo O, González S, Aroyo I, Pazos MR, Benito C, Lastres-Becker I, et al. Cannabinoid $\mathrm{CB}_{2}$ receptor agonists protect the striatum against malonate toxicity: relevance for Huntington's disease. Glia 2009; 57: 1154-67.

76 Pertwee RG. Emerging strategies for exploiting cannabinoid receptor agonists as medicines. Br J Pharmacol 2009; 156: 397-411. 